Journal of Advanced College of Engineering and Management, Vol. 6, 2021

\title{
ANALYSIS OF GRID TIED SOLAR ROOFTOP SYSTEM: A CASE STUDY ON STARS HOMES, SITAPAILA, NEPAL
}

\author{
Milana Prajapat ${ }^{2}$, Prof. Dr. Bharat RajPahar ${ }^{2}$,Asso. Prof. Dr. Shree Raj Shakya ${ }^{3}$
}

\begin{abstract}
Most of the nation demand is from the residential sector. Thus, the objective of this paper is to supply the required energy from the same demand point from the solar PV installed in the residential sector that is technically feasible for the given sector. The survey is conveyed on Star Homes(Residential Sector) situated at Sitapaila, Kathmandu. The total potential for installation of PV on useable areas of the rooftop of Stars Homes is calculated to be $253.2 \mathrm{kWp}$. For the comparative analysis in this paper, the isolated PV system is designed/ analysed using PV-SYST and the grid tied PV including/excluding battery is designed/analysed using SAM(System Advisory Model) software for one of the Type 1 home with annual demand of $2208 \mathrm{kWh}$. In grid interactive PV system with battery, the peak shaving and backup power during outage is facilitated and also the excess energy is supplied to the grid as well.Theenergy generated from the designed system for type I system with $3.9 \mathrm{kWp}$ grid tied system is $6483 \mathrm{kWh}$ and with $3.9 \mathrm{kWp}$ grid interactive system with battery size of 5.2kWh Lithium Ion is $6454 \mathrm{kWh}$ annually. Similarly, energy generated from designed system of standalone with $1.62 \mathrm{kWp}$ PV and battery size26V, 322Ah system is $3066.6 \mathrm{kWhannually} \mathrm{out} \mathrm{of} \mathrm{which} 795 \mathrm{kWh}$ is lost annually due to full battery charged conditions. The LCOE considering 25 years life time with $7.5 \%$ loan interest for 15 years for type I with standalone system is 21 cents $/ \mathrm{kWh}$, grid tied PV system is 4.94 cents $/ \mathrm{kWh}$ and with grid tied PV battery system is $6.73 \mathrm{cents} / \mathrm{kWh}$. The peak shaving obtained from the grid tied with battery system compared to the grid tied system is $0.8 \mathrm{~kW}$. The net saving on electricity bill for grid tied system is $516 \$$ and for grid tied system with battery is $526 \$$ annually considering net metering.
\end{abstract}

Keywords: Residential Sector - Solar Rooftop - Grid Tie - Battery

\section{Background}

Nepal is aiming to achieve high economic growth through its fifteenth national plan and become highly developed countries within 2100B.S. However, one of the key constraints of Nepal's development is energy security. Although Nepal is rich in hydropower resources, Nepal is unable to realize enough hydropower generation and fulfill the electricity demand internally. Moreover, Nepal has been declared load shedding free zone only after its door opened for massive import of electricity from the neighboring country, India. Nepal imported more than one third of electricity(42.3\%) from India last year(NEA, 2018-19). This has shown the status of Nepal as strivingfor energy and lagging in self independency in the field of energy.

Thus, solar PV systems could be potentially an attractive alternative for the energy hungry residential sector converting each house as a power source. Recently, doors have been open up by the National Planning Commission via sustainable development goals( SDG 7) which targetsto have access to electricity by $99 \%$ by introducing energy mix concept. The SDG has targeted to increase the share of the renewable energy upto $50 \%$ by 2030A.D.At present, in major cities of Nepal such as the Kathmandu Valley, rooftop solar PV's have not been broadly installed yet either by households or by commercial and industrial users due to non user friendly policy and unattractive subsidies from the government. Recently, the guidelines has been formulated by the Ministry of Energy for the netmetering of grid tied PV systems which allows owner of PV system to sell the excess energy generated to grid through net metering (MOE, 2017/18). This paper has focused to perform technofinancial analysis of the rooftop solar considering the net metering.

\section{Methodology}

The data required for the research work is collected at different levels. Climatic conditions, meteorological data, market conditions, national electricity grid conditions, national electricity tariff 
rates, available subsidy policy, domestic/residential user's survey data is obtained from relevant places. A survey on group of residential users of star homes (middle-upper class families) has been carried out in order to focus on category of potential users of PV grid connected system with battery backup through interview with the questionnaires prepared for the survey

The design for three cases i.e with Standalone system, Grid connected PV system and Grid interactive PV system with backupisdone.For all three cases, financial analysis is carried out considering net metering.

\section{Data Analysis}

The load profile data is graphed for all surveyed households. From the demand load data stored in TOD meter, the reliability (grid outage) of local distribution grid is also analyzed.

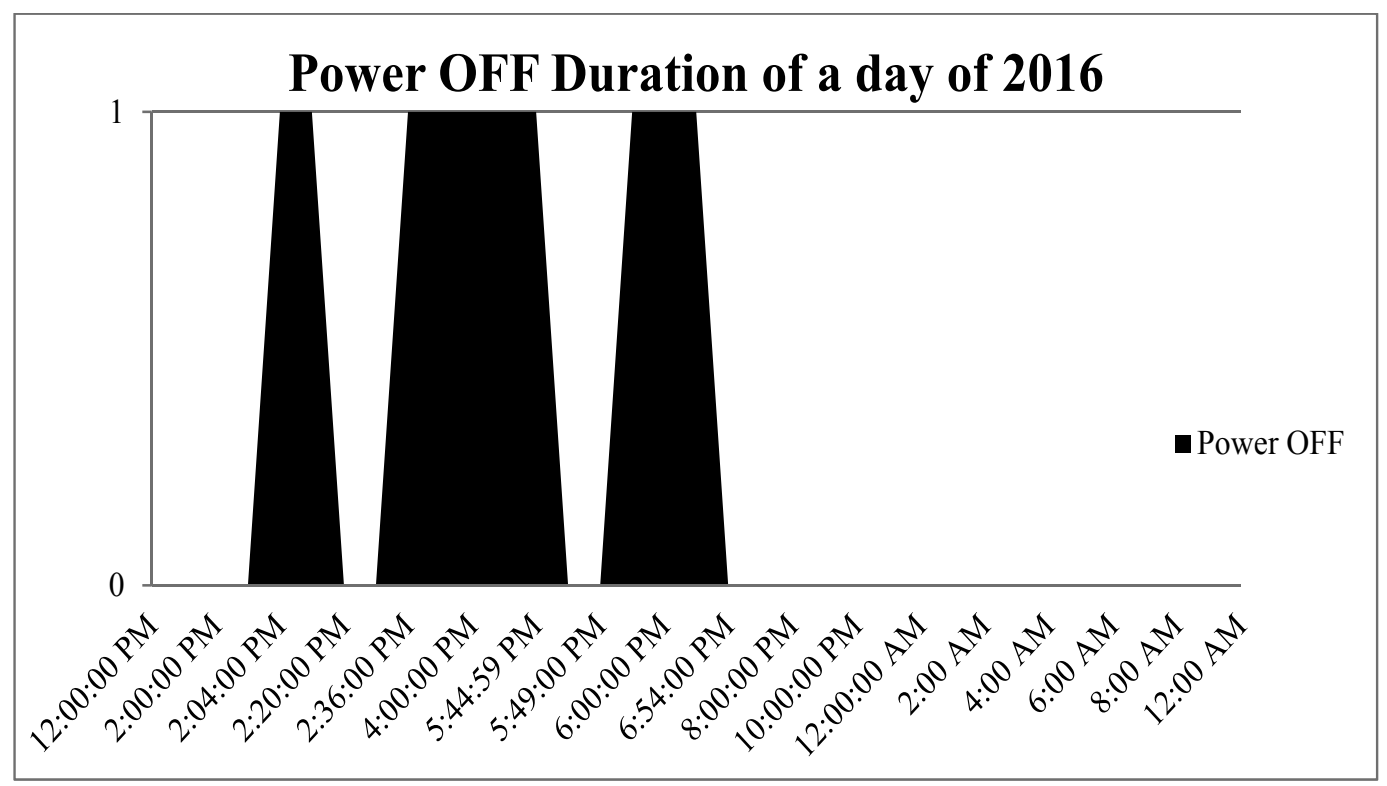

Fig 1: Outage of a certain day of the feeder feeding Stars Homes

\begin{tabular}{|l|l|l|l|l|l|l|l|l|}
\hline $\begin{array}{l}\text { S. } \\
\text { N }\end{array}$ & Type/No & Size & $\begin{array}{l}\text { Rooftop } \\
\left.\text { Area(m }{ }^{2}\right)\end{array}$ & Lad (VA) & $\begin{array}{l}\text { Area } \\
\text { including } \\
\text { all rooftop }\end{array}$ & $\begin{array}{l}\text { Usable area } \\
\text { for Solar } \\
\text { installation }\end{array}$ & $\begin{array}{l}\text { PV Potential( } \\
\mathrm{kWp}) 300 \mathrm{Wp} \\
@ 1.44 \mathrm{~m} 2\end{array}$ & $\begin{array}{l}\text { Total } \\
\text { potentialkWp }\end{array}$ \\
\hline 1 & Type I: 4 & Small & $<=60$ & $<2000$ & $52.3 \mathrm{~m}^{2}$ & $19 \mathrm{~m}^{2}$ & $3.9 \mathrm{kWp}$ & $4 * 3.9=15.6$ \\
\hline 2 & Type II:43 & Medium & $60-150$ & $\begin{array}{l}2000- \\
4500\end{array}$ & $123 \mathrm{~m}^{2}$ & $24 \mathrm{~m}^{2}$ & $4.8 \mathrm{kWp}$ & $43 * 4.8=206.4$ \\
\hline 3 & Type III:4 & Big & $>=150$ & $>4500$ & $165 \mathrm{~m}^{2}$ & $38 \mathrm{~m}^{2}$ & $7.8 \mathrm{kWp}$ & $4 * 7.8=31.2$ \\
\hline
\end{tabular}

Manual dimension measurement is carried out in order to calculate the usable rooftop area and the solar potential of rooftop area of each type of house. The houses of Stars homes are categorized according to the rooftop area and load as shown in the table.

Table 1: House type categorization and rooftop potential 


\section{Energy Consumption Pattern}

The energy consumption pattern of the houses that were surveyed are presented in the bar chart shown below:

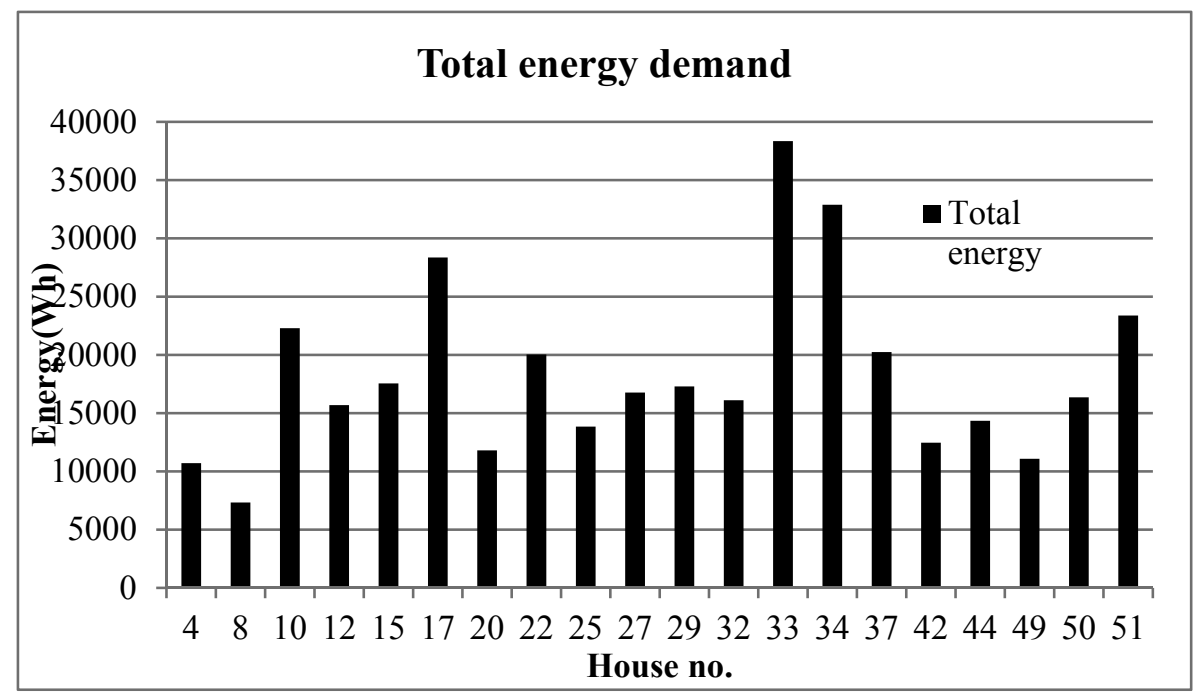

Fig 2: Bar chart of the Total Energy Consumption of Individual house in Weekend

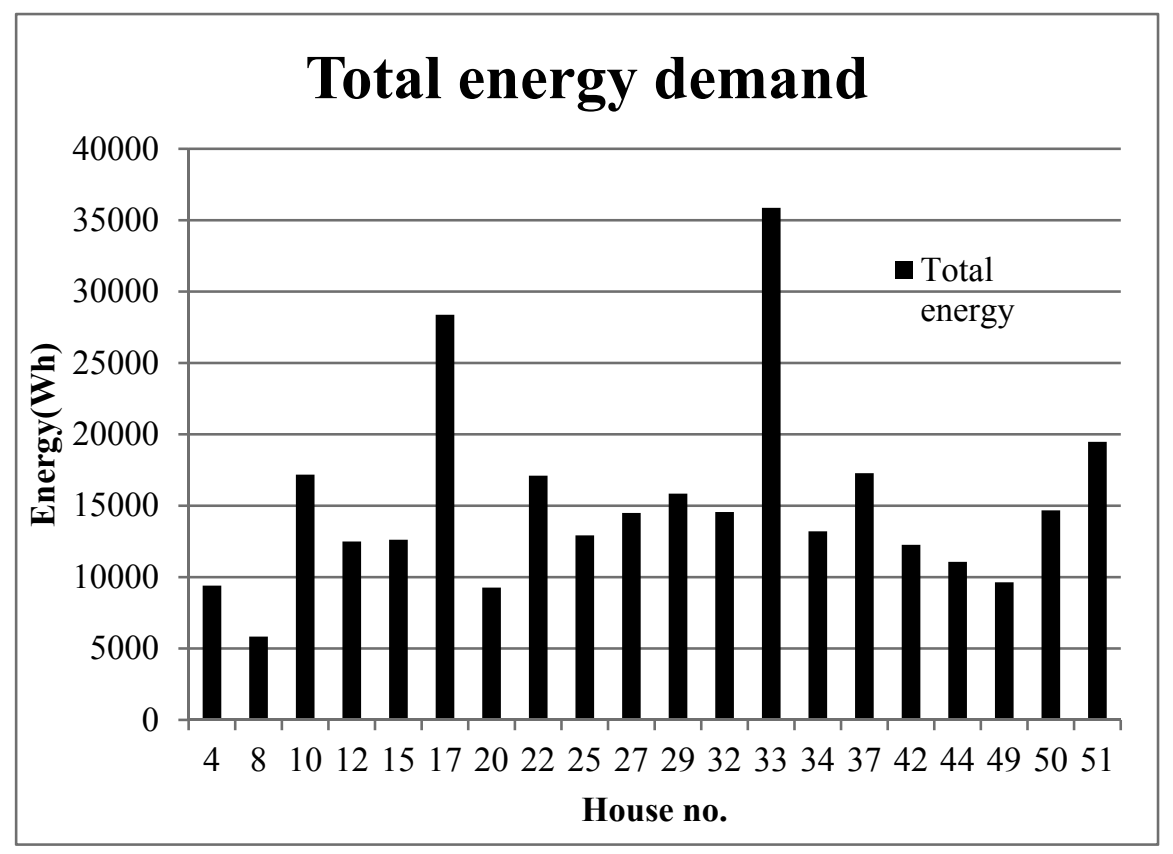

Fig 3: Bar chart of the Daily Energy Consumption of Individual house in Weekdays 


\section{Results}

Table 2:Design Summary of the Type 1 house

\begin{tabular}{|c|c|c|c|}
\hline Particular & $\begin{array}{l}\text { Standalone PV Design } \\
\text { for Type } 1\end{array}$ & $\begin{array}{l}\text { Grid Tied PV Design } \\
\text { for Type } 1\end{array}$ & $\begin{array}{l}\text { Grid Interactive PV } \\
\text { System with Battery } \\
\text { backup for Type } 1\end{array}$ \\
\hline $\begin{array}{l}\text { Installed } \\
\text { Capacity/Potential }\end{array}$ & $1.62 \mathrm{kWp}$ & $3.9 \mathrm{kWp}$ & $3.9 \mathrm{kWp}$ \\
\hline Solar Panel & $\begin{array}{l}6 \text { modules of } 270 \mathrm{Wp} \\
\text { of Canadian Solar } \\
\text { CS6P-270PMix }\end{array}$ & $\begin{array}{l}13 \text { modules of } 300 \mathrm{Wp} \\
\text { of Canadian Solar } \\
\text { CS1K300-MS }\end{array}$ & $\begin{array}{l}13 \text { modules of } 300 \mathrm{Wp} \\
\text { of Canadian Solar } \\
\text { CS1K300-MS }\end{array}$ \\
\hline Inverter & 2 kVA Luminous & $\begin{array}{l}2.962 \\
\text { kWSolarEdgeSE3000H- } \\
\text { US }\end{array}$ & $\begin{array}{l}3.68 \\
\text { kWSolarEdgeSE3680H- } \\
\text { RWSACBNN4 }\end{array}$ \\
\hline Battery & LFP-CB 26V $322 \mathrm{Ah}$ & No battery & $\begin{array}{l}5.2 \mathrm{kWh} \text { Tesla Lithium } \\
\text { Ion Battery }\end{array}$ \\
\hline
\end{tabular}

The stand alone system is designed and simulation is performed using PVsyst. The simulation results for the stand alonePV system is as shown below.

Normalized productions (per installed kWp): Nominal power $1620 \mathrm{Wp}$

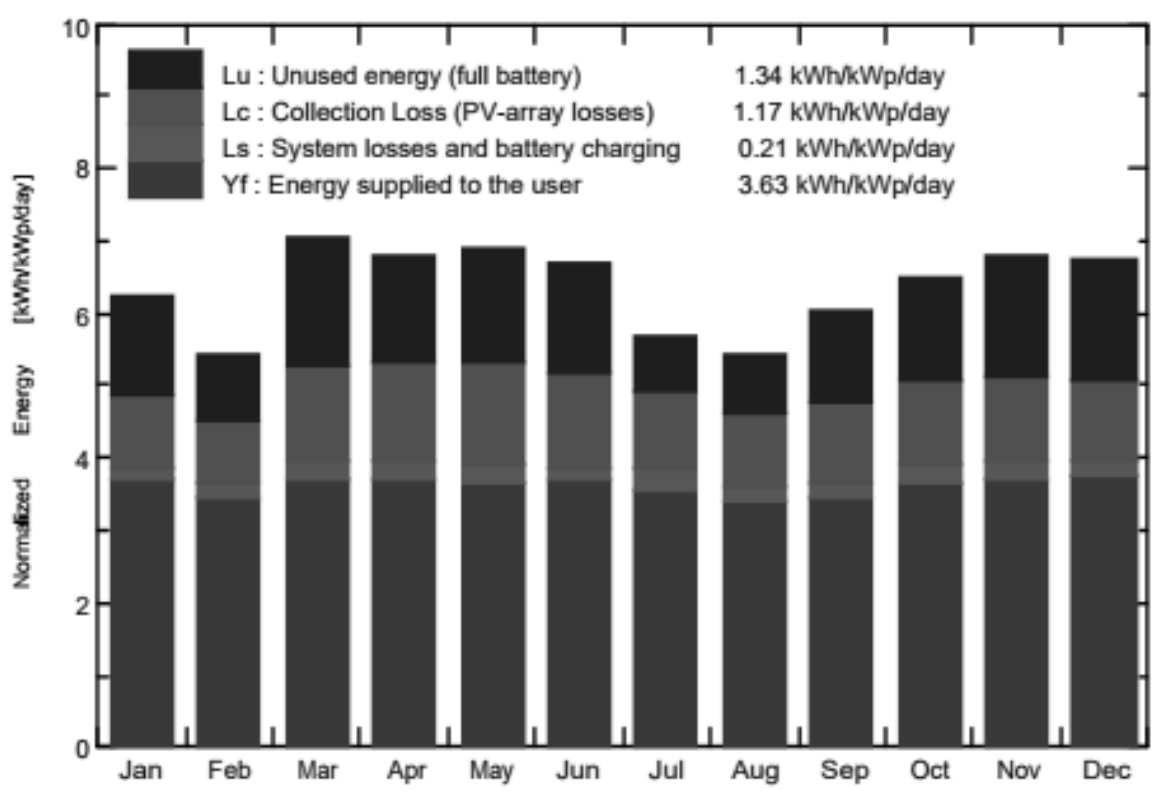

Fig 4: Energy production from the system from the standalone designed for Type I 


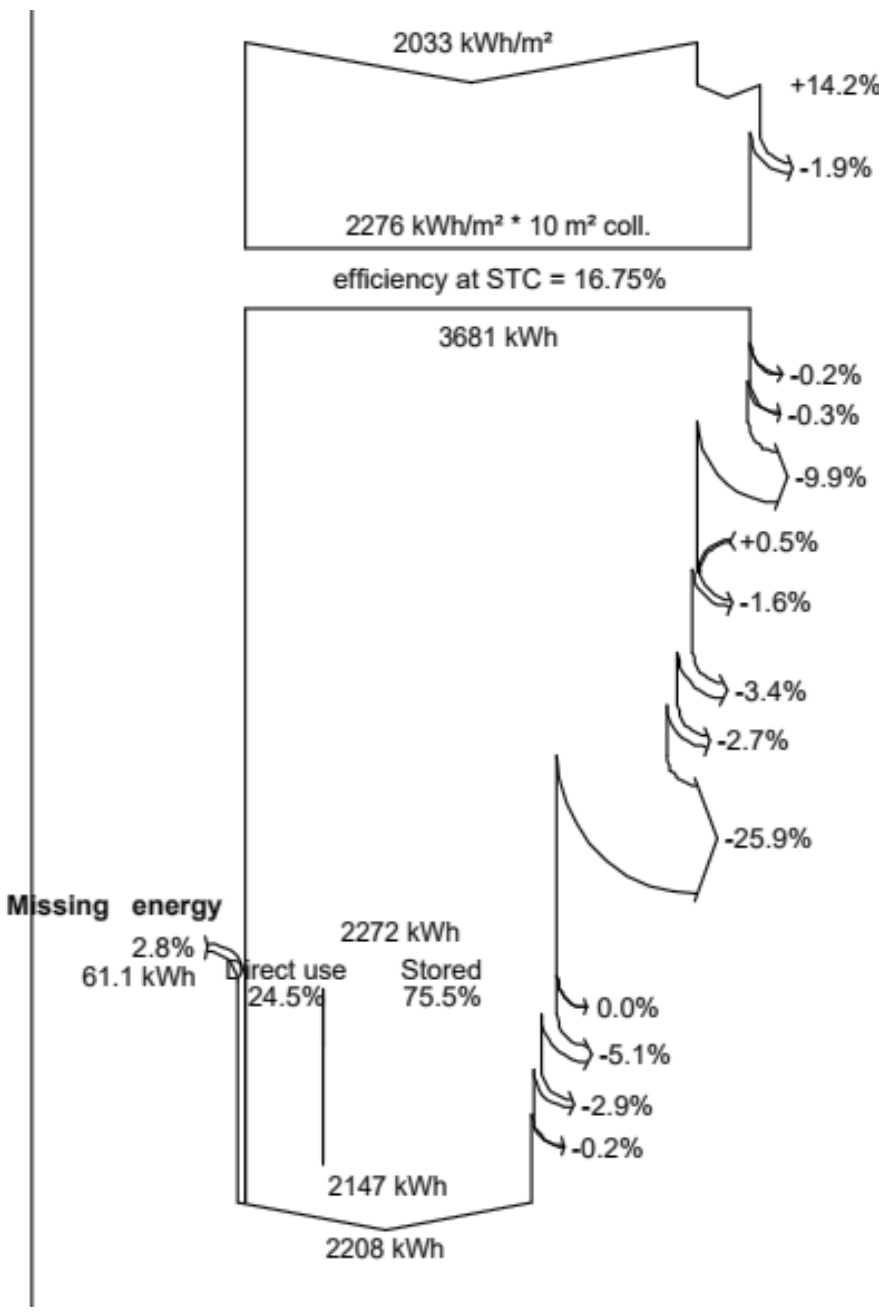

Horizontal global irradiation

Global incident in coll. plane

IAM factor on global

Effective irradiance on collectors

PV conversion

Array nominal energy (at STC effic.)

Module Degradation Loss ( for year \#1)

PV loss due to irradiance level

PV loss due to temperature

Module quality loss

Mismatch loss, modules and strings

(including $0 \%$ for degradation dispersion

Ohmic wiring loss

Loss by respect to the MPP running

Unused energy (full battery) loss

Effective energy at the output of the array

Battery Storage

Battery Stored Energy balance

Battery efficiency loss

Charge/Disch. Current Efficiency Loss

Battery Self-discharge Current

Energy supplied to the user

Energy need of the user (Load)

Fig5: Loss Diagram Over year

The above designed system has $2.8 \%$ missing energy and $25.9 \%$ energy lost due to some situations at which battery is fully charged and solar panel is generating excess energy than required by the load.

Another type of the design i.e. grid tied PV is designed using SAM. The simulation results for grid tied PV is as shown below.

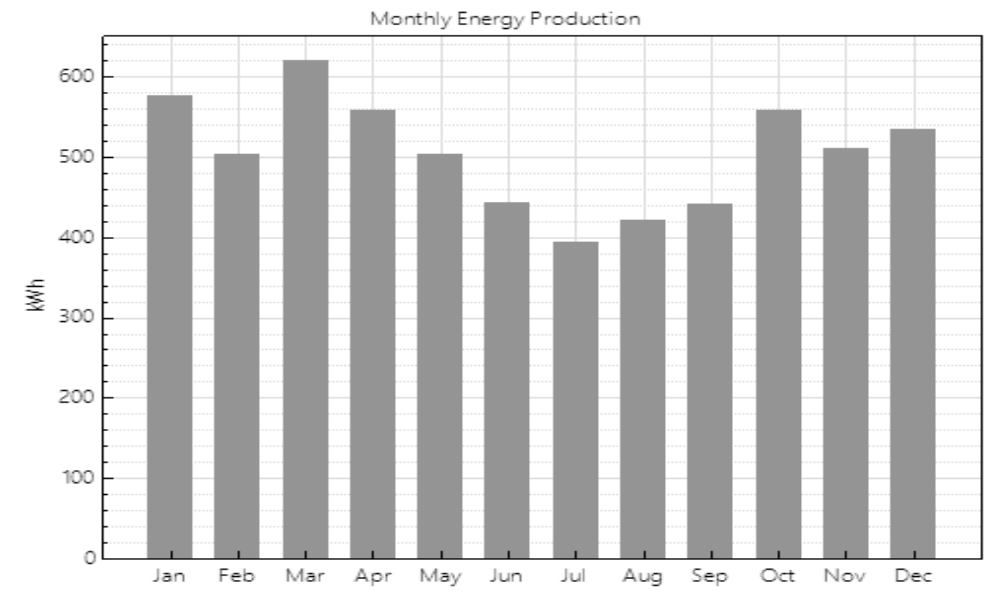

Fig 6: Generation from Grid Tied PV for Type I 
The graph shows the total AC energy supplied from PV, the electrical load and the surplus energy is cumulated every month and shown at the end of the year.

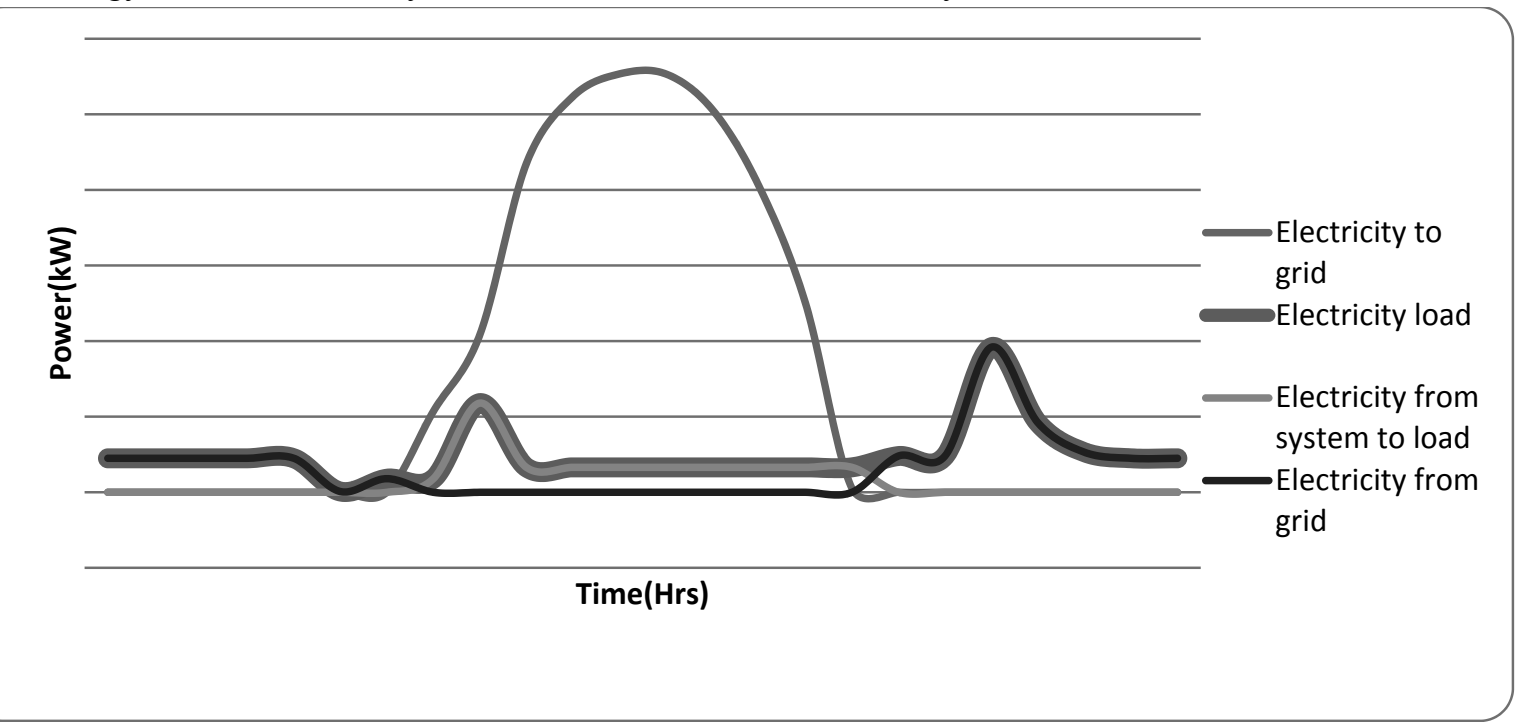

Fig 7: Electricity from PV to load, PV to grid, grid to load for Weekdays for Type I

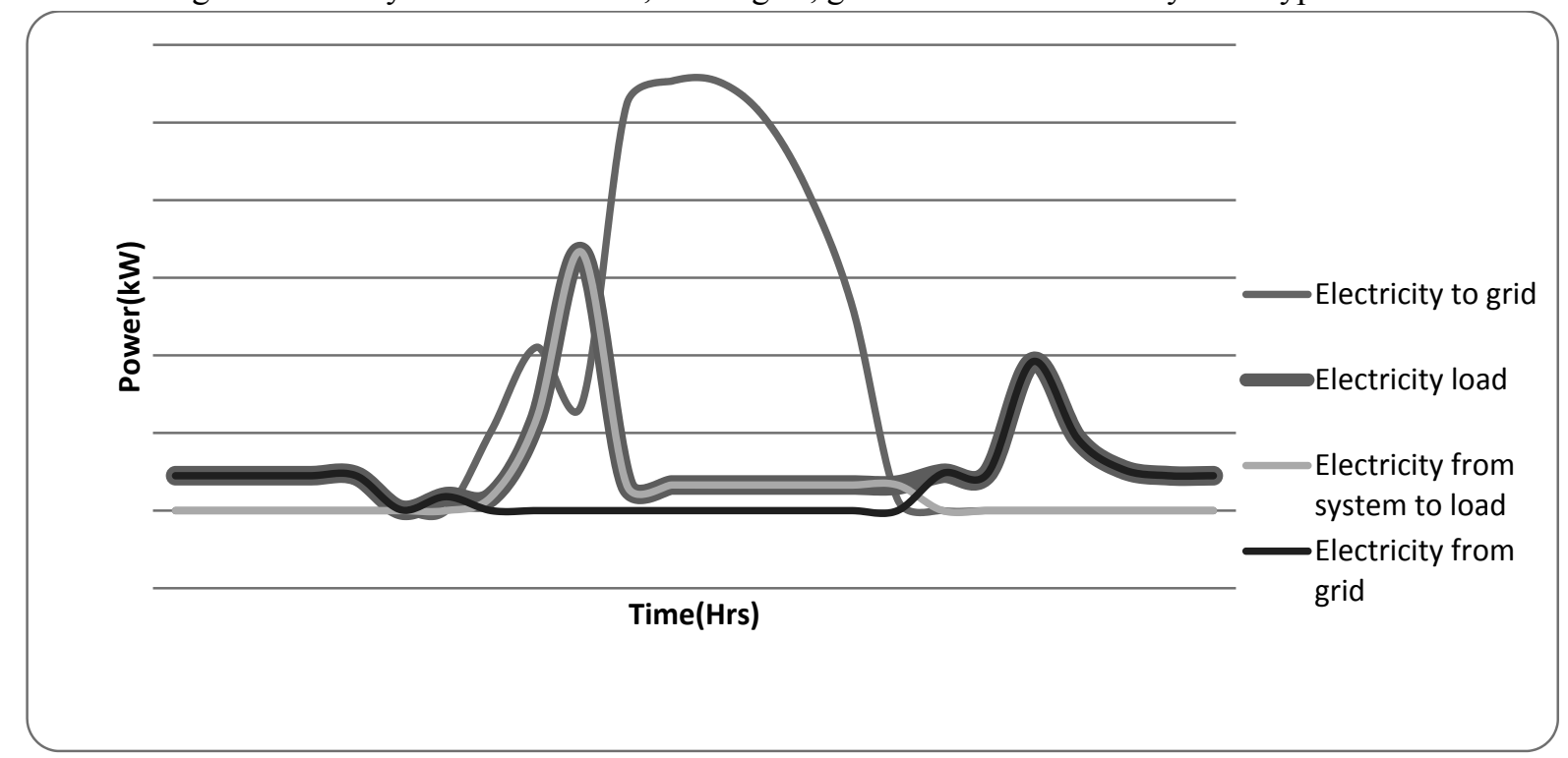

Fig 8: Electricity from PV to load, PV to grid, grid to load for Weekend for Type I

The grid tied PV with battery backup is designed using SAM. The simulation results for grid tied PV with battery backup is as shown below. 


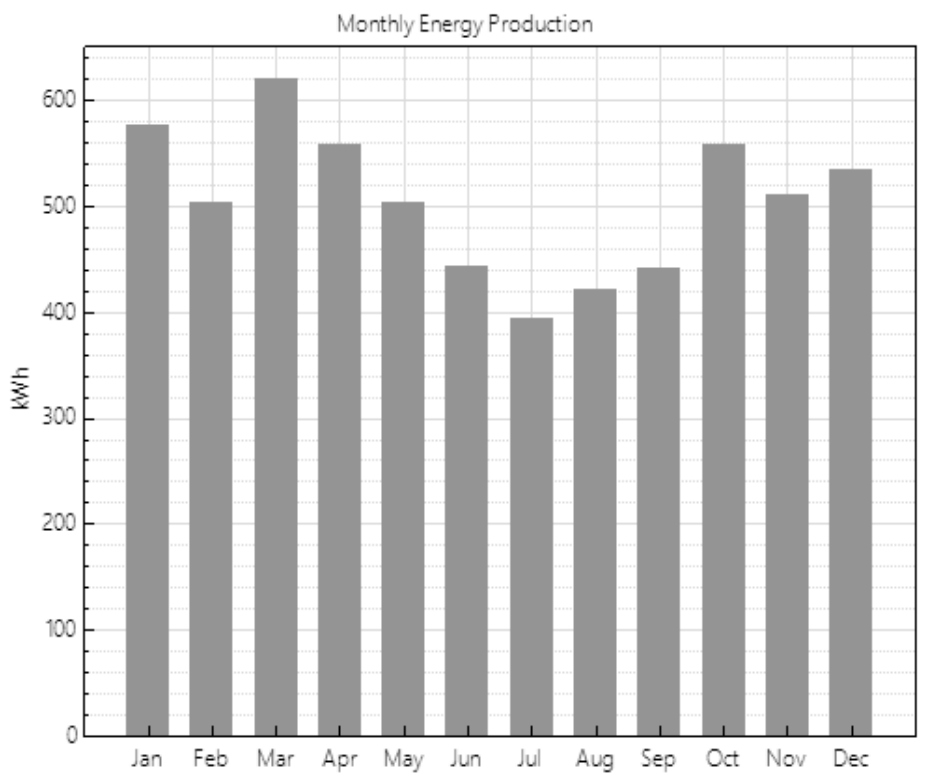

Fig 9: Generation from PV for Grid Tied with battery backup for Type I

The graph shows the total ac energy supplied from PV, the electrical load and the surplus energy is cumulated every month and shown at the end of the year.

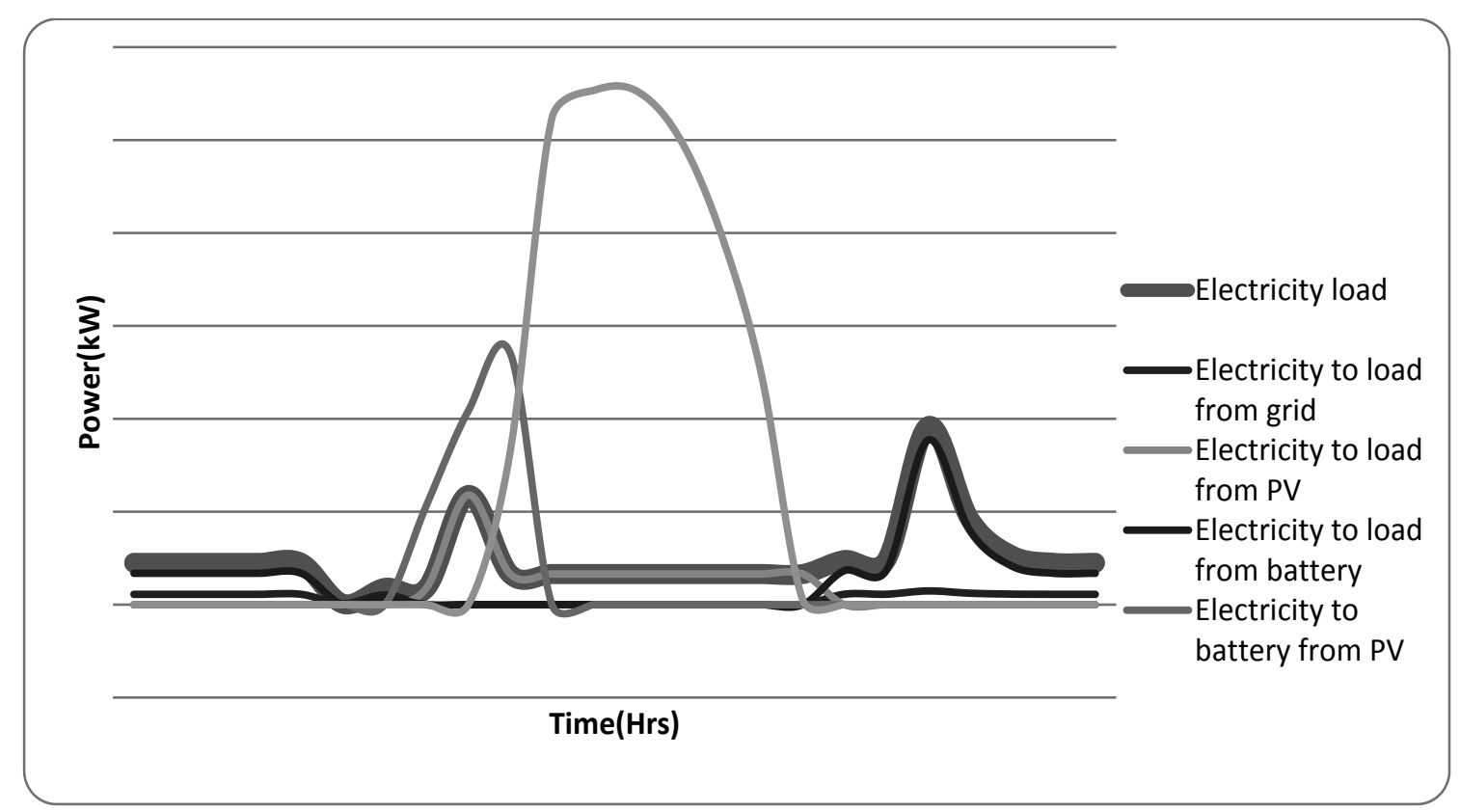

Fig 10: Electricity from PV to load and battery, PV and battery to grid, grid to load for Weekdays for Type I 


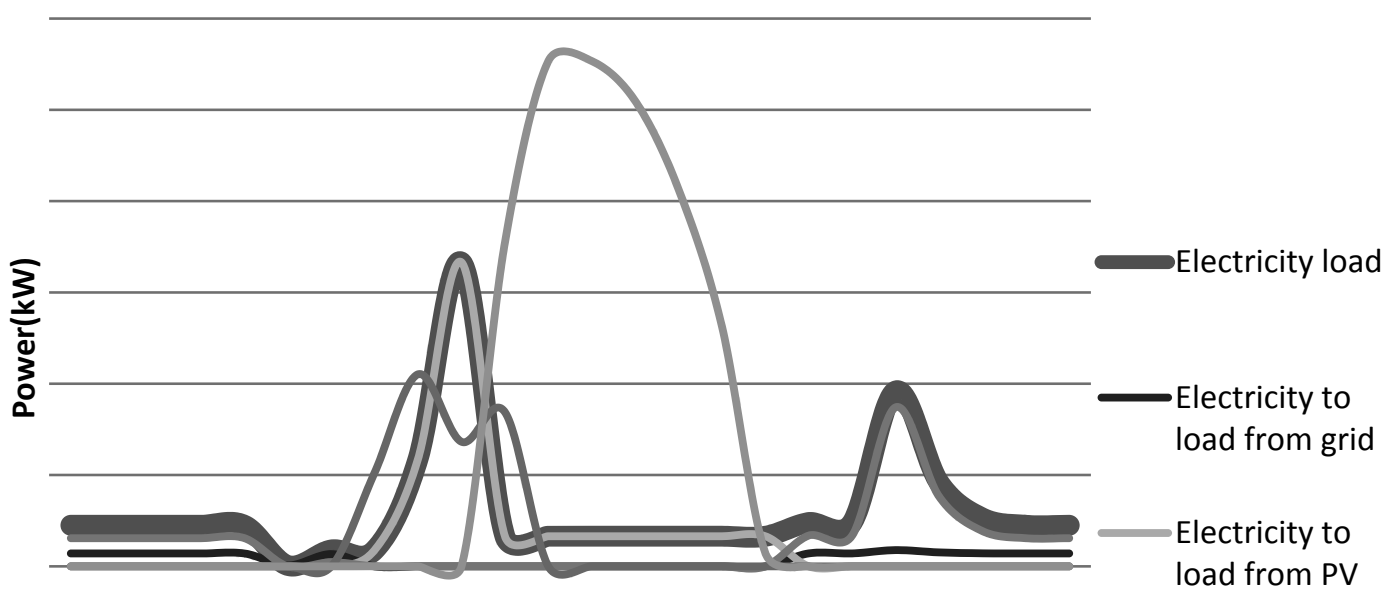

Time(Hrs)

Fig 11: Electricity from PV to load and battery, PV and battery to grid, grid to load for Weekend for Type I

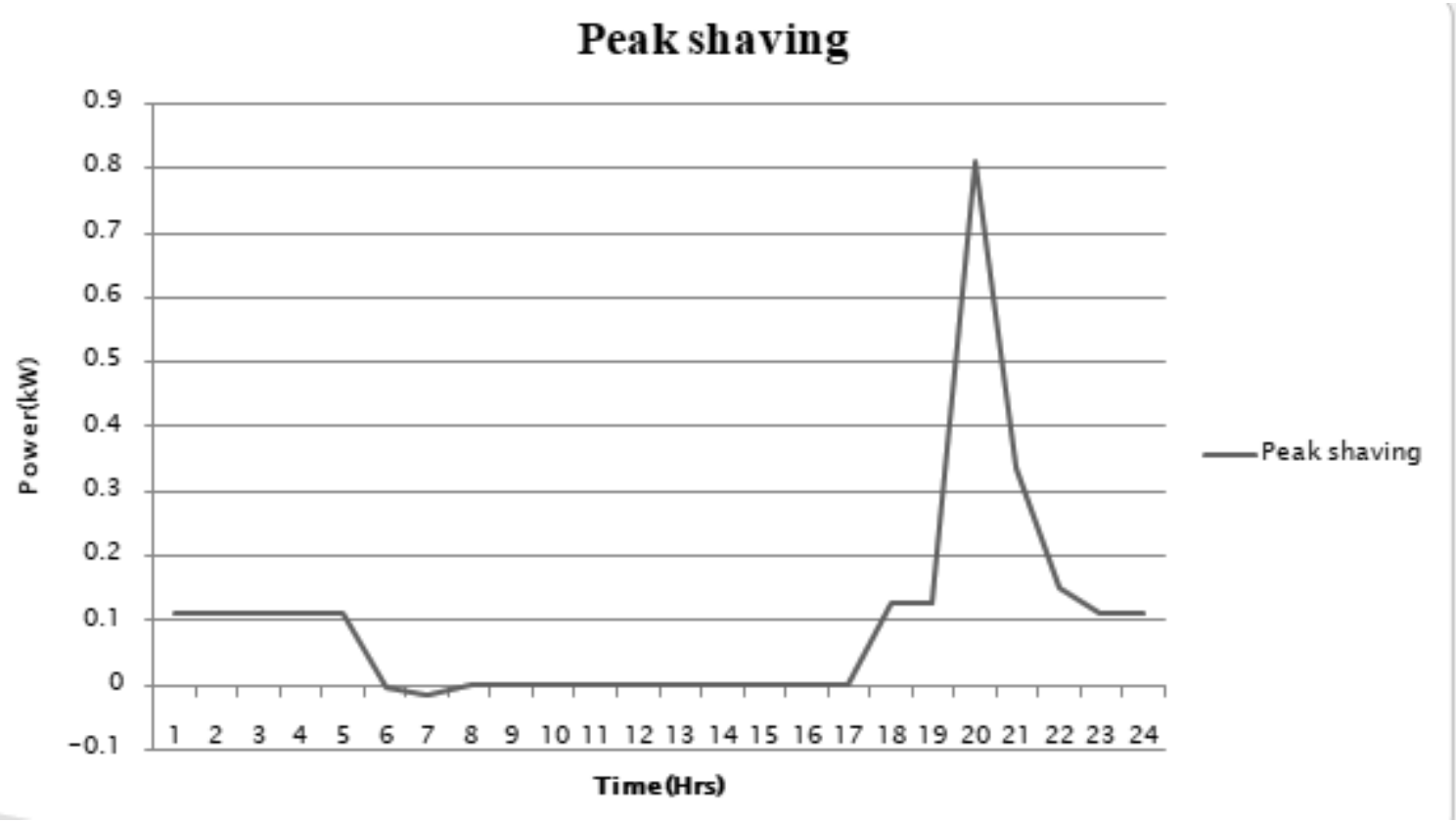

Fig 12: Peak shaving achieved in Grid Interactive PV with Battery Backup 
Table 3: Result Summary for the Type 1 House

\begin{tabular}{|c|c|c|c|}
\hline S.N & Financial Summary & $\begin{array}{l}\text { Software used } \\
\text { for simulation }\end{array}$ & Result (yearly) \\
\hline $\begin{array}{l}\text { Standalone } \\
\text { system }\end{array}$ & $\begin{array}{l}\text { Gross Investment } 2695 \mathrm{USD} \\
\text { @ loan rate of } 7.5 \% \\
\text { Energy Cost: } 0.21 \mathrm{USD} / \mathrm{kWh} \\
\text { Specific cost: } 1.66 \mathrm{USD} / \mathrm{Wp}\end{array}$ & PVSYST & $\begin{array}{l}\text { Load }=2208 \mathrm{kWh} \\
\text { Energy available }=3067 \mathrm{kWh} \\
\text { Excess Energy }=795 \mathrm{kWh} / \text { year } \\
\text { Energy }=1893 \mathrm{kWh} / \mathrm{kWp} \\
\text { Performance ratio: } 0.5709 \\
\text { Solar fraction }=0.9723\end{array}$ \\
\hline $\begin{array}{l}\text { Grid tied PV } \\
\text { system }\end{array}$ & $\begin{array}{l}\text { Gross Investment } 4312 \text { USD } \\
\text { @ loan rate of } 7.5 \% \\
\text { Energy Cost: } 0.066 \\
\text { USD/kWh } \\
\text { Specific cost: } 1.1 \mathrm{USD} / \mathrm{Wp}\end{array}$ & SAM & $\begin{array}{l}\text { Load }=2208 \mathrm{kWh} \\
\text { Energy PV= } 6066 \mathrm{kWh} \\
\text { Energy export }=5228 \mathrm{kWh} \\
\text { Energy import }=1369 \mathrm{kWh} \\
\text { Performance ratio }=0.82 \\
\text { Energy }=1683 \mathrm{kWh} / \mathrm{kWp}\end{array}$ \\
\hline $\begin{array}{l}\text { Grid } \\
\text { interactive } \\
\text { system with } \\
\text { backup }\end{array}$ & $\begin{array}{l}\text { Gross Investment } 5182 \text { USD } \\
\text { @ loan rate of } 7.5 \% \\
\text { Energy Cost: } 0.08 \mathrm{USD} / \mathrm{kWh} \\
\text { Specific cost: } 1.3 \mathrm{USD} / \mathrm{Wp}\end{array}$ & $\begin{array}{l}\text { SAM(peak } \\
\text { shaving dispatch } \\
\text { model to aid } \\
\text { INPS grid) }\end{array}$ & $\begin{array}{l}\text { Load }=2208 \mathrm{kWh} \\
\text { Energy PV }=6003 \mathrm{kWh} \\
\text { Energy export }=4320 \mathrm{kWh} \\
\text { Energy import }=524 \mathrm{kWh} \\
\text { Performance ratio }=0.81 \\
\text { Energy }=1665 \mathrm{kWh} / \mathrm{kWp} \\
\text { Battery charged from }\end{array}$ \\
\hline
\end{tabular}

\section{Sensitivity Analysis}

For the billing analysis, three scenarios is considered. The first scenarios is the block tariff structure which the tariff structure applied to the residential sector by NEA. The nest scenario is the Time of Day tariff structure. Since this type of tariff structure is not applicable in the residential sector, so the tariff structure of the commercial sector for the $11 \mathrm{kV}$ consumer is applied. And the other scenario is the average rate of the block rate tariff structure applied to the residential sector.

The sensitivity analysis on the Grid tied PV system is as follows:

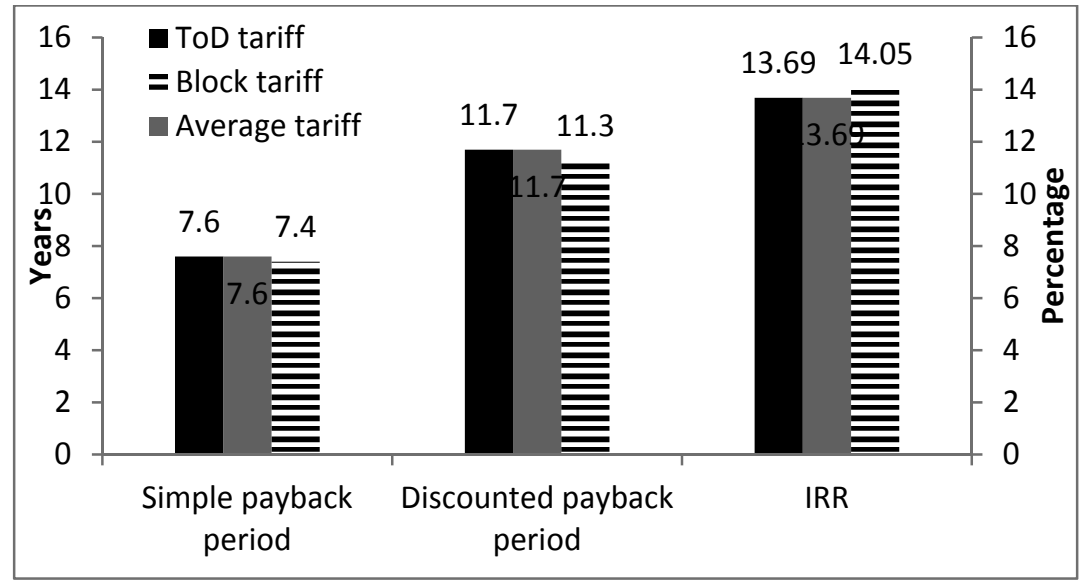

Fig 13: Sensitivity analysis for payback period and IRR for Grid Tied System 


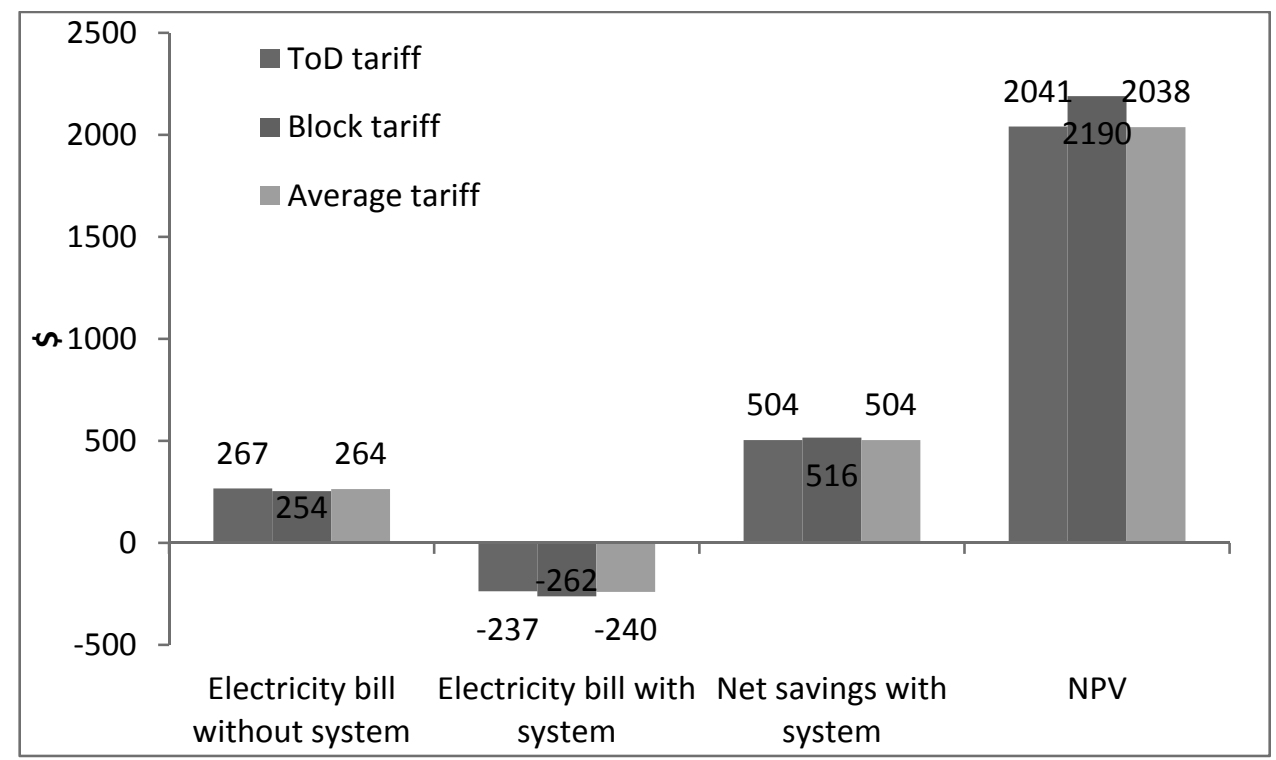

Fig 14: Sensitivity analysis for the different tariff structure in Grid tied system

The sensitivity analysis on the Grid tied PV system with battery is as follows:

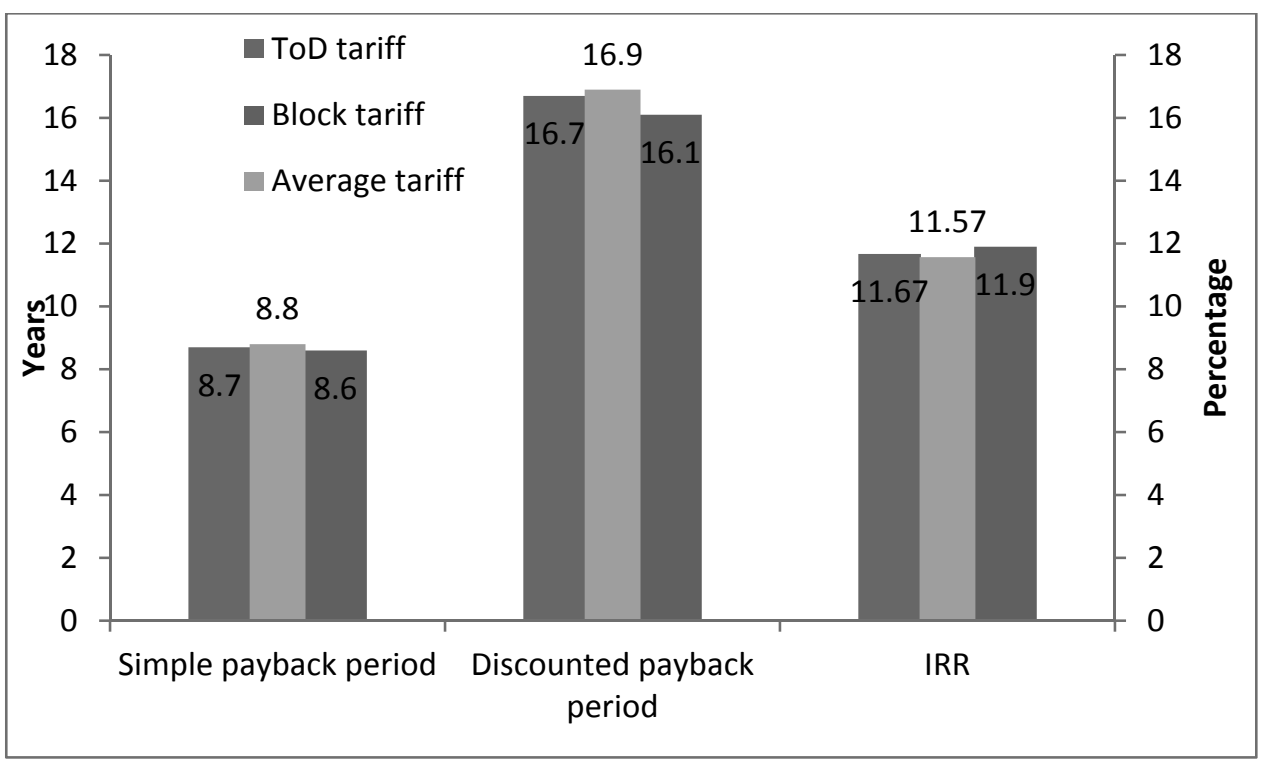

Fig 15: Sensitivity analysis for payback period and IRR for Grid Tied with Battery backup 


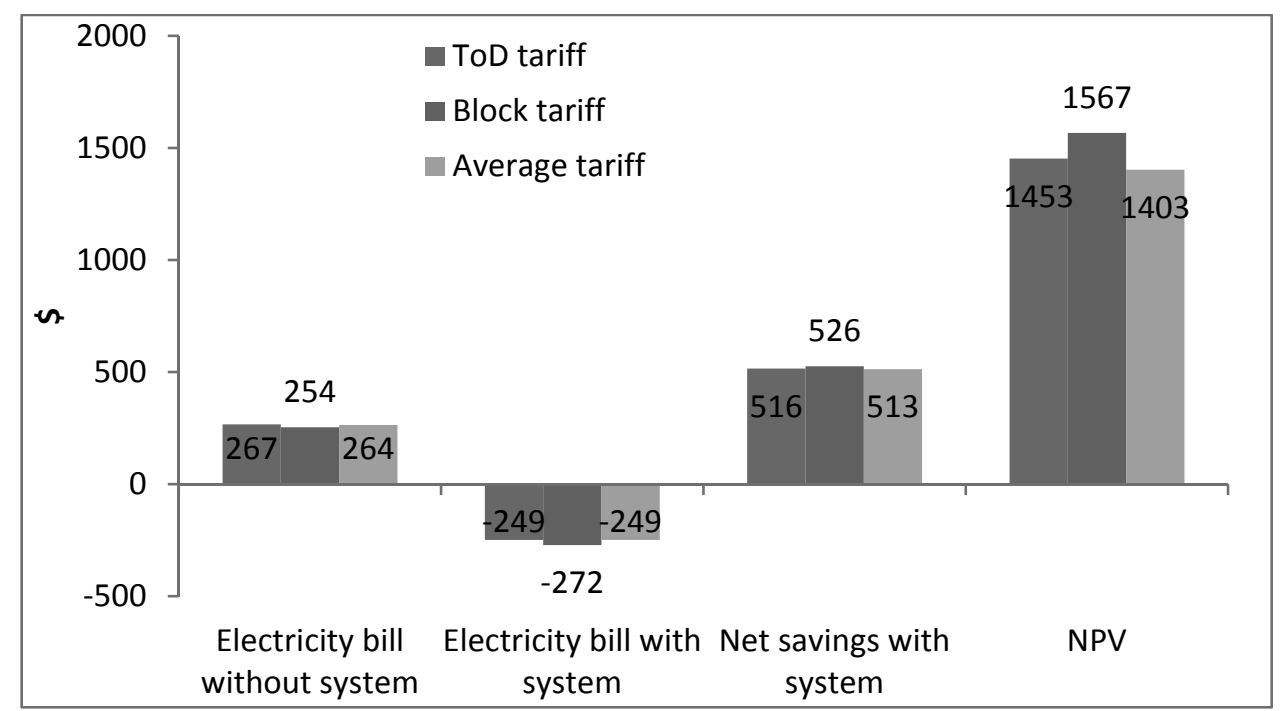

Fig 16: Scenario analysis for the different tariff structure in Grid tied system with Battery

\section{Comparative Analysis}

The comparative analysis for the system with and without battery is tabulated below

Table 4: Comparative analysis of the grid tied system with and without battery

\begin{tabular}{|l|l|c|c|}
\hline S.N. & Parameters & Grid Tied System & Grid Tied System with Battery \\
\hline 1 & Annual energy $(\mathrm{kWh})$ & 6483 & 6459 \\
\hline 2 & Capacity factor(\%) & 19 & 18.9 \\
\hline 3 & Energy yield(kWh/kW) & 1660 & 1654 \\
\hline 4 & Performance ratio & 0.8 & 0.8 \\
\hline 5 & Battery efficiency li ion(\%) & & 91.78 \\
\hline 6 & Nominal LCOE(cents/kWh) & 7.03 & 8.37 \\
\hline 7 & Real LCOE(cents/kWh) & 4.94 & 5.88 \\
\hline 8 & Electricity bill without system $(\$)$ & 254 & 254 \\
\hline 9 & Electricity bill with system(\$) & -262 & -272 \\
\hline 10 & Net savings with system(\$) & 516 & 526 \\
\hline 11 & NPV(\$) & 2190 & 1567 \\
\hline 12 & Simple payback period(years) & 7.4 & 8.6 \\
\hline 13 & Discounted payback period(years) & 11.3 & 16.1 \\
\hline 14 & Net capital cost $(\$)$ & 4311.95 & 5182.09 \\
\hline 15 & Cost per capacity $(\$ /$ Wdc $)$ & 1.1 & 1.33 \\
\hline 16 & IRR(\%) & 14.05 & 11.9 \\
\hline
\end{tabular}




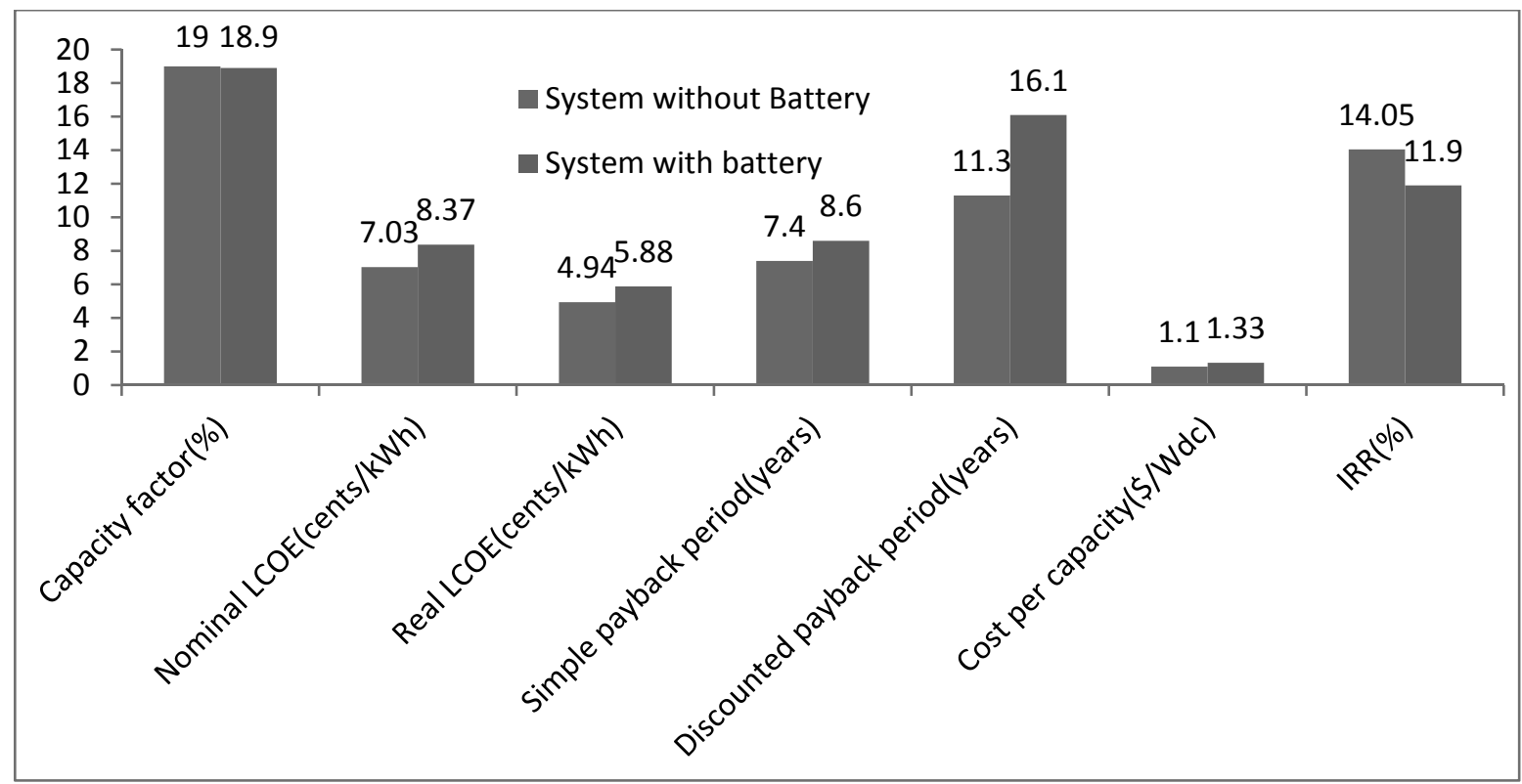

Fig 17: Comparison of Grid Tied System with and without battery

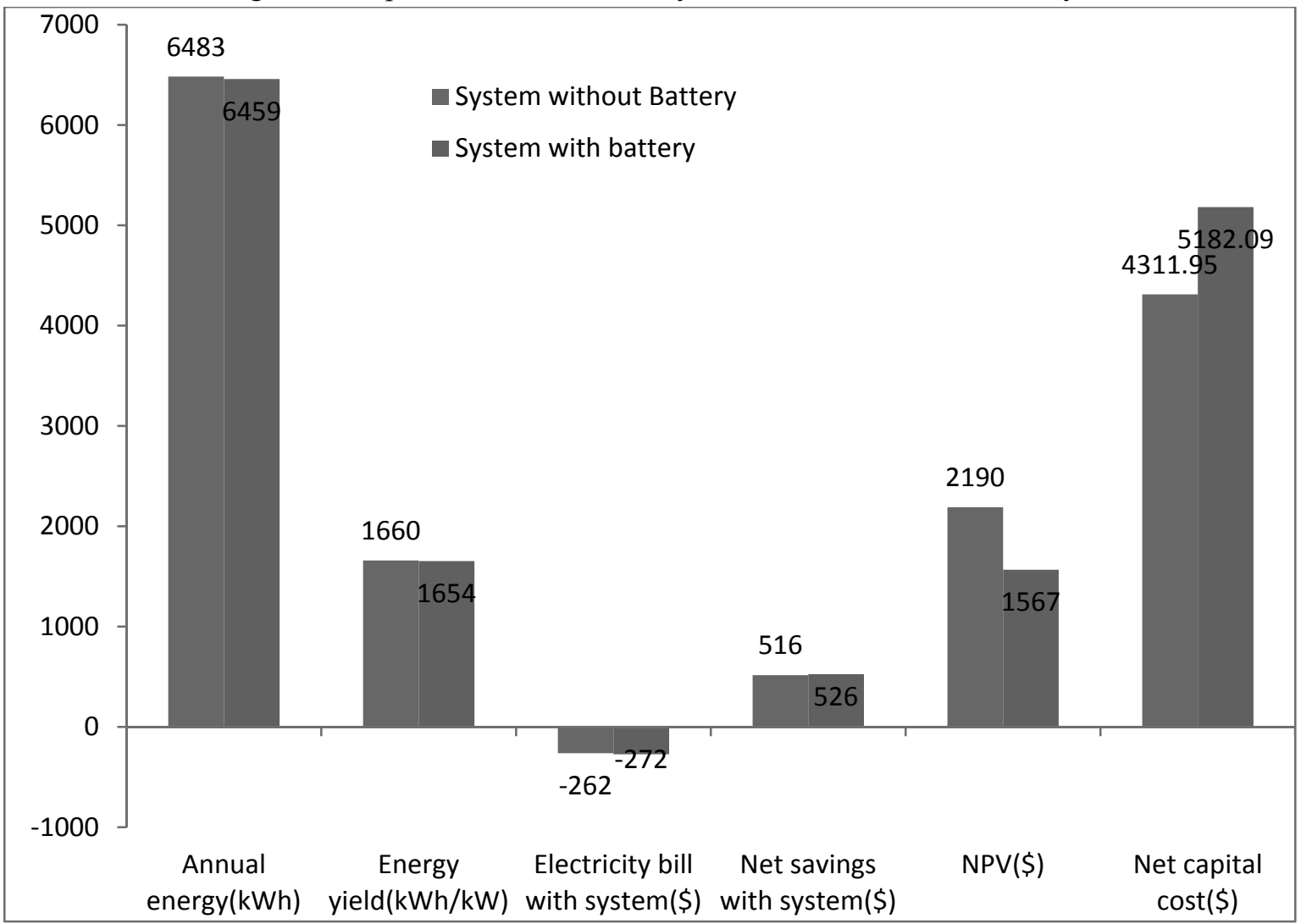

Fig 18: Comparison of Grid Tied System with Battery and without Battery 


\section{Conclusions}

According to the house type and the survey performed, type 1 house has maximum load of $1665 \mathrm{~W}$ with energy demand of $2208 \mathrm{kWh}$ yearly, type 2 house has maximum load of $2350 \mathrm{~W}$ with energy demand of $4487 \mathrm{kWh}$ yearly and type 3 house has maximum load of $4175 \mathrm{~W}$ with energy demand of $8167 \mathrm{kWh}$. The total potential for installation of PV on useable areas of the rooftop of Stars Homes is calculated to be $253.2 \mathrm{kWp}$. This paper analyses the three types of design on type 1 house i.e. standalone PV system, grid tied PV system and grid interactive system with battery backup.In standalone system, PVSYST simulation results show the designed system of $1620 \mathrm{Wpis}$ capable to match the load for type 1 of the building and thus, it is independent from the grid but the excess generated energy is being wasted during the situation of fully charged battery condition and minimal demand of load than generation. Energy generated from the designed system of $3.9 \mathrm{kWpfor}$ type I system with grid tied system is $6483 \mathrm{kWh}$ and with grid tied battery system is $6454 \mathrm{kWh}$. The LCOE considering 25 years life time with $7.5 \%$ loan interest for 15 years for type I with grid tied system is 4.94 cents $/ \mathrm{kWh}$ and with grid tied battery system is $5.88 \mathrm{cents} / \mathrm{kWh}$. This system aids the grid than the traditional inverter battery backup system which takes grid power to store the energy in the battery.

Similarly, the peak shaving obtained from the grid tied with battery system compared to the grid tied system is $0.8 \mathrm{~kW}$. The net saving on electricity bill for grid tied system is $516 \$$ and for grid tied system with battery $526 \$$.

\section{Assumptions/ Limitation}

a) The surveyed load profile is assumed similar for similar type of houses. Thus, its average is used for the design. However, data logger in each house would only give exact real load profile data for accurate design. The load profile of similar house type is averaged assuming they have similar daily requirement.

b) Many hesitated to answer the questions. Many were unaware of technical terms. Thus, the reliability of surveyed data cannot be assured.

c) As the Nepal market is still unaware of the grid connected inverters accessories, lithium ion batteries, their cost shall be assumed from the international market without considering custom and transportation charges. 


\section{References}

1. http://www.bpthoughtacademy.org/news/40/renewable-energy-energy-mix-and-energysecurity -in-Nepal

2. Presentation on "Freeing the Grid Solar PV System for Kathmandu" on 9 July 2014 at Kathmandu ,Santosh Mani Nepal.

3. Presentation on "Policy Need for Deployment of Rooftop Solar PV Systems in Urban Areas of Nepal " on 9 July 2014 at Kathmandu , A Nakarmi, Center for Energy Studies

4. https://energypedia.info/wiki/Nepal_Energy_Situation

5. http://www.tradingeconomics.com/nepal/electric-power-consumption-kWh-per-capita-wbdata.html

6. http://nea.org.np/images/supportive_docs/year-review-2014-15.pdf

7. Jagan Nath Shrestha, Domenico Chianese, Davide Rivola, Alex Zahnd "Impact of Small Decentralized PV Grid - Connected Plants on Load Shedding in Nepal" Nepal Solar Energy Society, Kathmandu, Nepal,University of Applied Sciences and Arts of Southern Switzerland (SUPSI), Switzerland RIDS-Nepal, Kathmandu, Nepal

8. D. Chianese, D. Pittet, J.N. Shrestha, D. Sharma, A. Zahnd ,N. Sanjel, M. Shah and M Uphadyaya ,2009, "Feasibility study on Grid connected PV system in Nepal" ,Institute for Applied Sustainability to the Built Environment, University of Applied Science of Southern Switzerland - SUPSINSES and Center for Energy Studies, Institute of Engineering, Tribhuvan University RIDS-Nepal (NGO) and Kathmandu University

9. Zhou Wu, Henerica Tazvinga, Xiaohua Xia, "Demand side management of photovoltaicbattery hybrid system "

10. Reena Shrestha ,2069 "Techno-Economic Analysis of Grid Connected Rooftop Solar PhotovoltaicSystem (A case study of Pulchowk Campus) “, M Sc. Thesis ,Department of Mechanical Engineering, Pulchowk Campus, Tribhuvan University.

11. Thomas Stobaugh, Senior Project, ELECTRICAL ENGINEERING DEPARTMENT, California Polytechnic State University, San Luis Obispo,2012 "Residential Grid-Tied Photovoltaic (PV) System With Battery Backup ".

12. Nabraj Bhattarai, 2004,"Study on Grid-Connected PV Systems in Nepal",MSc Thesis, Department of Mechanical Engineering, Pulchowk Campus, Tribhuvan University.

13. White Paper from EfficientCarbon"Rooftop Solar and Net Metering in India - A Detailed Analysis ".

14. Ahmed G. Abo-Khalil, Electrical Engineering Department, Assiut University, Egypt "Design and Simulation of a Grid-Connected Photovoltaic System for the EE Department Building in Assiut University".

15. SundarBahadurKhadka, 2012 " Design analysis of institutional solar PV and its financial feasibility in Nepal "M.Sc Thesis, Department of Mechanical Engineering, Tribhuvan University.

16. Ajay Bhattarai, 2069, "Performance Analysis of One Kilowatt Grid Connected Solar Photovoltaic (pv) Electric System." M.Sc Thesis, Department of Mechanical Engineering, Tribhuvan University.

17. Ukesh Shrestha, 2014, "Techno-Economic Analysis of Utility Scale Photovoltaic Plant(A Case Study of One MWp Plant at Trishuli)" M.Sc Thesis, Department of Mechanical Engineering, Tribhuvan University.

18. PravaThapaChettri, 2015," Prototype Net Zero Energy Contemporary Residential Building for Kathmandu Valley", M.Sc Thesis, Department of Mechanical Engineering, Tribhuvan University.

19. Ambish Kaji Shakya, 2015, "Case study on Grid Integrated Solar PV for National Dasarath Stadium", M.Sc Thesis, Department of Mechanical Engineering, Tribhuvan University. 